\title{
Effect of Added Arabinoxylans Isolated from Good and Poor Chapati Making Wheat Varieties on Rheological Properties of Dough and Chapati Making Quality
}

\author{
Mysore S. Hemalatha ${ }^{1}$, Ragu Sai Manohar ${ }^{2}$, Paramahans V. Salimath ${ }^{1}$, \\ Ummiti J. S. Prasada Rao ${ }^{{ }^{*}}$ \\ ${ }^{1}$ Biochemistry and Nutrition Department, Central Food Technological Research Institute, Mysore, India; ${ }^{2}$ Flour Milling, Baking and \\ Confectionary Technology Department, Central Food Technological Research Institute, Mysore, India. \\ Email: "prasadarao_ummiti@yahoo.com
}

Received June $14^{\text {th }}, 2013$; revised July $14^{\text {th }}, 2013$; accepted July $21^{\text {st }}, 2013$

Copyright (C) 2013 Mysore S. Hemalatha et al. This is an open access article distributed under the Creative Commons Attribution License, which permits unrestricted use, distribution, and reproduction in any medium, provided the original work is properly cited.

\begin{abstract}
Arabinoxylans are the major non-starch polysaccharides in wheat and are reported to influence quality of bakery products. Arabinoxylans were isolated from good and poor chapati making varieties, added them at different levels $(0.25$ and $0.5 \mathrm{~g} / 100 \mathrm{~g}$ ) to the same flour, interchanged with other varieties and determined the effect of arabinoxylans on rheological properties of dough and chapati making quality. Rheological properties were improved upon adding isolated arabinoxylans of good chapati making varieties to flours. Interestingly, addition of isolated arabinoxylans of good chapati making varieties to poor chapati making varieties had significantly improved the chapati quality. Sensory studies showed that chapatis prepared from flour added with arabinoxylans of good chapati varieties had soft texture and high overall quality scores. These changes are attributed to differences in their arabinose/xylose ratio. Thus, results indicated that addition of isolated arabinoxylans of good chapati making flour improved the chapati quality of poor chapati making flour.
\end{abstract}

Keywords: Wheat; Arabinoxylans; Rheology; Chapati

\section{Introduction}

Wheat (Triticum aestivum) is a major cereal crop used for the preparation of bakery products such as bread, biscuits and cakes all over the world. However, in India, about $75 \%$ of the wheat grown is used for the preparation of chapati, an unleavened flat bread, which is prepared from whole wheat flour. Chapati is the main traditional wheat based food, consumed by majority of the population in Indian subcontinent and also widely consumed in UK and other countries by Asian ethnic community [1]. The desired sensory quality characteristics of chapati are greater pliability, soft texture, light creamish brown colour, slight chewiness and baked wheat aroma [2]. Carbohydrate is the major component present in whole wheat flour and among the carbohydrates, starch is the major component and arabinoxylan is the minor component [3]. Arabinoxylans contents vary from 5 to $8 \%$ of the whole grain flour [4] while in refined wheat flour its

${ }^{*}$ Corresponding author. content is very low $(2 \%-3 \%)$.

Arabinoxylans are also referred to as pentosans and they are the major non-starch polysaccharides present in wheat [5]. Due to their high water binding capacity water soluble arabinoxylans are known to play an important role in rheological properties of dough [6], retrogradation of starch and breadmaking quality $[7,8]$. Addition of water soluble arabinoxylans to refined wheat flour significantly increased the farinograph water absorption and dough development time and also increased bread quality parameters like loaf volume, crumb structure and decreased staling characteristics $[9,10]$.

Although considerable work has been reported with respect to the role of arabinoxylans on bread quality, no reports are available with respect to whole wheat flour products such as parotta, chapati, roti, etc. Therefore, the present work was undertaken to study the effect of added water soluble arabinoxylans from good and poor chapati making wheat varieties on rheological properties of dough and chapati making quality. 


\section{Materials and Methods}

\subsection{Wheats}

Four Triticum aestivum wheat varieties namely DWR162 and DWR-39, were procured from University of Agricultural Sciences, Dharwad, India and HD-2189 and MACS-2496 were procured from Agharkar Research Institute, Pune, India. DWR-162 and DWR-39 were reported as good varieties for chapati making property, while HD-2189 and MACS-2496 were poor varieties for chapati making property [11]. Wheat was milled in a commercial disc mill to obtain whole wheat flour $(\leq 400$ $\mu)$.

\subsection{Isolation of Arabinoxylans}

Arabinoxylans from whole-wheat flour of different wheat varieties were isolated according to the method described by Santos et al. [12]. Whole-wheat flours were fractionated into starch, gluten and water-solubles [13]. Water-soluble arabinoxylans were isolated and purified. The arabinoxylans present in the water solubles were precipitated from the supernatant at $80 \%$ ethanol. The precipitate was then washed and dried by exchange of solvents, followed by drying at $30^{\circ} \mathrm{C}[14,15]$.

\subsection{Analytical Methods}

Estimation of total sugars was carried out according to the method described by Dubois et al. [16] and uronic acids were estimated according to the method described by Dische [17]. Sugar composition in the flour and water-insoluble fractions were analysed after solubilization with $72 \%$ sulphuric acid (in ice-cold temperature) followed by hydrolysis in $10 \%$ sulphuric acid at boiling water bath temperature for $6-8 \mathrm{~h}$. The water-soluble fractions were hydrolysed with $2 \mathrm{~N}$ trifluroacetic acid in sealed tubes at $100^{\circ} \mathrm{C}$ for $5-6 \mathrm{~h}$. The sugars were analysed by gas liquid chromatography as alditol acetates [18] on OV-225 column at column temperature at $200^{\circ} \mathrm{C}$ using Shimadzu GLC. Arabinoxylan content was determined according to the method described by Albaum and Umbreit [19].

\subsection{Rheological Characteristics}

Farinograph characteristics of whole wheat flours were determined according to AACC [20] method using Brabender Farinograph-E (Brabender OHG, Duisburg, Germany). Whole wheat flours were enriched with 0.25 $\mathrm{g} / 100 \mathrm{~g}$ and $0.5 \mathrm{~g} / 100 \mathrm{~g}$ of water soluble arabinoxylans and their farinograph characteristics were studied.

The amylograph characteristics of whole wheat flours were determined using Micro Visco Amylograph (Bra- bender OHG, Duisburg, Germany). Whole wheat flours were enriched with $0.25 \mathrm{~g} / 100 \mathrm{~g}$ and $0.5 \mathrm{~g} / 100 \mathrm{~g}$ of water soluble arabinoxylans and their amylograph characteristics were studied. Whole wheat flours (15 g on 14\% moisture basis) were suspended in $100 \mathrm{ml}$ of distilled water and heated in the visco-amylograph from $30^{\circ} \mathrm{C}$ to $92^{\circ} \mathrm{C}$ at a rate of $5^{\circ} \mathrm{C} / \mathrm{min}$, held at $92^{\circ} \mathrm{C}$ for $5 \mathrm{~min}$, cooled to $50^{\circ} \mathrm{C}$ and then held at $50^{\circ} \mathrm{C}$ for 1 min under constant stirring (250 rpm). Torque measuring range was $300 \mathrm{cmg}$. The viscosity was expressed in Brabender Units (BU).

\subsection{Chapati Making Quality}

Chapatis were prepared by adding water soluble arabinoxylans to whole wheat flour. Control chapati was prepared without addition of water soluble arabinoxylans. Chapati dough was prepared by mixing $200 \mathrm{~g}$ flour and water equivalent to chapati dough water absorption in a Hobart mixer (Model N-50) at speed 1 (61 rpm) for 3 min and rested for 20 minutes according to Haridas Rao et al. [1]. The sheeted dough $(1.5 \mathrm{~mm})$ was cut into a circular shape of $15 \mathrm{cms}$ diameter using a die and the cut dough was baked on a hot plate at $215^{\circ} \mathrm{C}$ for $70 \mathrm{~s}$ on side 1 and $85 \mathrm{~s}$ on side 2 . The chapati was then transferred to a heated gas tandoor oven $\left(370^{\circ} \mathrm{C}\right)$ in such a way that side 1 was placed on the grill and heated for $10 \mathrm{~s}$. Height of the puffed chapati was measured as soon as the chapati was removed from the tandoor oven according to Haridas Rao et al. [1]. The puffed chapati was then cooled, packed in polypropylene pouches and stored at room temperature until further use.

\subsection{Objective and Subjective Evaluation of Chapati}

The texture of chapati was evaluated by using the texture analyzer (Stable Micro Systems, Model TA-HD, UK) using the Warner Bratzler blade (HDP/BSW). Three strips measuring $5 \times 2.5 \mathrm{~cm}$ from each chapati were cut. One strip at a time was placed on the centre of the sample holder and allowed the blade to cut the chapati strip. The force $(\mathrm{N})$ required to cut the chapati strip into 2 pieces was recorded. The cross-head speed was maintained at $100 \mathrm{~mm} / \mathrm{min}$. Measurement for four chapatis were recorded and average value was reported.

A panel of ten experienced judges carried out the sensory evaluation of chapatis. The product was evaluated for color and appearance (colour of the spots and their uniformity), tearing strength, pliability and mouthfeel (soft, tough, leathery), taste and aroma (sweetish, wheat, and bland) and overall quality (sum of all the attributes). The panellists were asked to provide the scores on the basis of the quality description given against each sensory attribute evaluated. 


\subsection{Statistical Analysis and Graphical Representation}

The experimental data, including sensory scores of chapati, were treated statistically by Duncan's new multiple range test (DMRT) to determine the significance ( $\mathrm{p} \leq$ $0.05)$ of results [21].

\section{Results and Discussion}

\subsection{Composition of Whole Wheat Flour}

Chemical characteristics and carbohydrate profile of DWR-162, DWR-39, HD-2189 and MACS-2496 whole wheat flours are given in Table 1. Damaged starch contents were high in DWR-162 and DWR-39 wheat varieties, whereas the protein content is low compared to MACS-2496 wheat varieties. The falling number of HD2189 and MACS-2496 wheat flours are high (664 and 577 ) indicating that it has low $\alpha$-amylase activity compared to the other two whole wheat flours. The SDS sedimentation values were high for DWR-162 and DWR39 flours indicating that the whole wheat flours are strong compared to HD-2189 and MACS-2496 whole wheat flours. However, the carbohydrate content varied from 71 to $76 \mathrm{~g} / 100 \mathrm{~g}$ in the whole wheat flours. The arabinoxylan contents of DWR-162 and DWR-39 wheat varieties were $4.7 \mathrm{~g} / 100 \mathrm{~g}$ and $4.1 \mathrm{~g} / 100 \mathrm{~g}$, respectively, which were higher than the other two varieties (3.0 and $3.2 \mathrm{~g} / 100 \mathrm{~g}$ ). The arabinose-xylose ratios of DWR-162 and DWR-39 wheat varieties were high indicating that it might be due to higher degree of branching in these arabinoxylans. Higher degree of branching was reported in few Canadian wheat flours of variable bread making quality [8]. The arabinose-xylose ratios (A/X) of HD2189 and MACS-2496 wheat varieties were low indicating that it might be due to lower degree of branching in these arabinoxylans [22].

\subsection{Composition of Isolated Arabinoxylans}

The arabinoxylans isolated from DWR-162 and DWR-39 whole wheat flours were high compared to the arabinoxylan isolated from HD-2189 and MACS-2496 whole wheat flours (Table 1). The isolated arabinoxylans were lesser than the native arabinoxylan contents in whole wheat flours. The total sugar content of isolated arabinoxylans varied from 82.7 to $88.5 \mathrm{~g} / 100 \mathrm{~g}$. The arabinose-xylose ratios of arabinoxylans isolated from DWR162 and DWR-39 wheat varieties which are known to have good chapati making property were high (1.7) indicating that it might be due to higher degree of branching in these arabinoxylans. Saxena et al. [23] have also reported that the contents of arabinose and xylose were higher in the polysaccharide fractions of varieties of wheat that have good tandoor roti-making quality. The arabinosexylose ratios of arabinoxylans isolated from HD-2189 and MACS-2496 wheat varieties were low (0.95) indicating that it might be due to lower degree of branching in these arabinoxylans.

\subsection{Effect of Arabinoxylans on the Farinograph Characteristics of Whole Wheat Flour}

\subsubsection{Effect of Arabinoxylans on the Same Variety of Whole Wheat Flour}

Arabinoxylans isolated were added at 0.25 and 0.5 $\mathrm{g} / 100 \mathrm{~g}$ in the same variety of whole wheat flour and farinograph characteristics of the same were studied (Table 2). Water absorption (WA) increased from 77.8 to $80 \%$ and $82.2 \%$ in DWR-162 flour while the increase in WA was from $75.5 \%$ to $77.5 \%$ and $80.5 \%$ in DWR-39 flour on addition of 0.25 and $0.5 \mathrm{~g} / 100 \mathrm{~g}$ arabinoxylans of the same variety, respectively. The increase in WA was $2.0 \%$ to $5 \%$ for these two good chapati making variety flours, whereas only $0.3 \%$ to $0.6 \%$ increase in WA was observed for poor chapati making quality flours obtained from HD-2189 and MACS-2496 varieties. Dough development time (DDT) decreased from 3.7 to 3.3 and 3.2 min for DWR-162 flour while the decrease in DDT was from 3.9 to 3.6 and $3.4 \mathrm{~min}$ for DWR-39 flour on addition of 0.25 and $0.5 \mathrm{~g} / 100 \mathrm{~g}$ arabinoxylans of the same variety, respectively. The decrease in DDT was 0.3 to 0.5 min for these two good chapati making variety whole wheat flours, whereas only 0.1 to $0.2 \mathrm{~min}$ decrease in DDT was observed for poor chapati making quality

Table 1. Chemical characteristics of whole wheat flour (WWF) and isolated arabinoxylans.

\begin{tabular}{|c|c|c|c|c|c|c|c|c|c|c|c|}
\hline \multirow[b]{2}{*}{$\begin{array}{c}\text { Wheat } \\
\text { Varieties }\end{array}$} & \multirow[b]{2}{*}{$\begin{array}{l}\text { Moisture } \\
\text { (g/100g) }\end{array}$} & \multirow[b]{2}{*}{$\begin{array}{l}\text { Damaged } \\
\text { Starch } \\
(\mathrm{g} / 100 \mathrm{~g})\end{array}$} & \multirow[b]{2}{*}{$\begin{array}{l}\text { Protein } \\
(\mathrm{g} / 100 \mathrm{~g})\end{array}$} & \multirow[b]{2}{*}{$\begin{array}{l}\text { Falling } \\
\text { Number } \\
\text { (sec) }\end{array}$} & \multirow[b]{2}{*}{$\begin{array}{c}\text { SDS } \\
\text { Sedimentation } \\
\text { Value (ml) }\end{array}$} & \multirow[b]{2}{*}{$\begin{array}{l}\text { Arabinoxylan } \\
\text { content } \\
(\mathrm{g} / 100 \mathrm{~g})\end{array}$} & \multirow[b]{2}{*}{$\begin{array}{l}\text { Total Sugar } \\
(\mathrm{g} / 100 \mathrm{~g})\end{array}$} & \multicolumn{2}{|c|}{ Isolated arabinoxylans } & \multicolumn{2}{|c|}{ A/X Ratio ${ }^{*}$} \\
\hline & & & & & & & & $\begin{array}{l}\text { Yield in } \\
\text { WWF } \\
(\mathrm{g} / 100 \mathrm{~g})\end{array}$ & $\begin{array}{l}\text { Total Sugar } \\
\text { (g/100g) }\end{array}$ & WWF & $\begin{array}{c}\text { Isolated } \\
\text { Arabinoxylan }\end{array}$ \\
\hline DWR-162 & $7.2^{\mathrm{b}} \pm 0.1$ & $17.1^{\mathrm{b}} \pm$ & $12.7^{\mathrm{b}}$ & $0^{\mathrm{d}} \pm 11$ & $59^{b} \pm 1$ & $4.7^{\mathrm{a}} \pm 0.2$ & $75.2^{b} \pm 0.3$ & 3.0 & $86.3^{\circ} \pm 0.7$ & 1.24 & 1.69 \\
\hline DWR-39 & $7.3^{\mathrm{b}} \pm 0.2$ & $17.6^{\mathrm{a}} \pm 0.3$ & $12.3^{\mathrm{c}} \pm 0.3$ & $461^{\mathrm{c}} \pm 8$ & $62^{\mathrm{a}} \pm 2$ & $4.1^{\mathrm{b}} \pm 0.1$ & $74.4^{b} \pm 0.2$ & 3.0 & $82.7^{\mathrm{c}} \pm 0.4$ & 1.25 & 1.7 \\
\hline HD-2189 & $7.6^{\mathrm{a}} \pm 0.1$ & $15.8^{\mathrm{c}} \pm 0.3$ & $11.8^{\mathrm{c}} \pm 0.2$ & $664^{\mathrm{a}} \pm 12$ & $50^{\mathrm{c}} \pm 2$ & $3.0^{\mathrm{c}} \pm 0.5$ & $76.1^{\mathrm{a}} \pm 0.95$ & 2.3 & $84.8^{\mathrm{b}} \pm 0.5$ & 0.72 & 0.94 \\
\hline MACS-2496 & $6.7^{\mathrm{c}} \pm 0.2$ & $12.3^{\mathrm{d}} \pm 0.1$ & $14.6^{\mathrm{a}} \pm 0$. & $577^{b} \pm 14$ & $53^{d} \pm 2$ & $3.2^{\mathrm{c}} \pm 0.2$ & $71.2^{\mathrm{c}} \pm 0.2$ & 2.0 & $88.5^{\mathrm{a}} \pm 0.5$ & 0.91 & 0.96 \\
\hline
\end{tabular}

Data reported are expressed as mean $\pm \mathrm{SD}$; Means followed by different letters in the same column differ significantly $(\mathrm{p} \leq 0.05)$; ${ }^{*} \mathrm{~A} / \mathrm{X}$ Ratio is arabinose to xylose ratio. 
Table 2. Rheological characteristics of whole wheat flour on addition of isolated arabinoxylans.

\begin{tabular}{|c|c|c|c|c|c|c|c|c|c|}
\hline \multirow[b]{2}{*}{$\begin{array}{c}\text { Wheat } \\
\text { Varieties }\end{array}$} & \multirow[b]{2}{*}{ Variations (Arabinoxylans) } & \multicolumn{3}{|c|}{ Farinograph Characteristics } & \multirow[b]{2}{*}{$\begin{array}{c}\text { Tolerance } \\
\text { Index (BU) }\end{array}$} & \multicolumn{4}{|c|}{ Amylograph Characteristics } \\
\hline & & $\begin{array}{c}\text { Water } \\
\text { Absorption } \\
(\%)\end{array}$ & $\begin{array}{c}\text { Dough } \\
\text { Development } \\
\text { Time (min) }\end{array}$ & $\begin{array}{l}\text { Dough } \\
\text { Stability } \\
\text { (min) }\end{array}$ & & $\begin{array}{c}\text { Pasting } \\
\text { Temperature } \\
\left({ }^{\circ} \mathrm{C}\right)\end{array}$ & $\begin{array}{c}\text { Peak } \\
\text { Viscosity } \\
\text { (BU) }\end{array}$ & $\begin{array}{l}\text { Hot Paste } \\
\text { Viscosity } \\
\text { (BU) }\end{array}$ & $\begin{array}{c}\text { Cold Paste } \\
\text { Viscosity } \\
\text { (BU) }\end{array}$ \\
\hline \multirow[t]{5}{*}{ DWR-162 } & Control & 77.8 & 3.7 & 2.8 & 38 & 67.7 & 470 & 370 & 581 \\
\hline & $0.25 \mathrm{~g} / 100 \mathrm{~g}$ a-DWR-162 & 80.0 & 3.3 & 2.5 & 43 & 67.3 & 712 & 670 & 816 \\
\hline & $0.5 \mathrm{~g} / 100 \mathrm{~g}$ a-DWR-162 & 82.2 & 3.2 & 2.2 & 51 & 67.1 & 864 & 820 & 946 \\
\hline & $0.25 \mathrm{~g} / 100 \mathrm{~g}$ a-HD-2189 & 78.1 & 3.6 & 1.9 & 54 & 66.4 & 536 & 433 & 640 \\
\hline & $0.5 \mathrm{~g} / 100 \mathrm{~g}$ a-HD-2189 & 78.4 & 3.4 & 1.8 & 47 & 65.6 & 601 & 475 & 716 \\
\hline \multirow[t]{5}{*}{ DWR-39 } & Control & 75.5 & 3.9 & 2.5 & 56 & 67.3 & 530 & 454 & 628 \\
\hline & $0.25 \mathrm{~g} / 100 \mathrm{~g}$ a-DWR-39 & 77.5 & 3.6 & 2.2 & 86 & 67.2 & 776 & 741 & 886 \\
\hline & $0.5 \mathrm{~g} / 100 \mathrm{~g}$ a-DWR-39 & 80.5 & 3.4 & 2.1 & 73 & 66.4 & 842 & 793 & 926 \\
\hline & $0.25 \mathrm{~g} / 100 \mathrm{~g}$ a-MACS-2496 & 75.8 & 7.8 & 3.9 & 33 & 66.2 & 552 & 474 & 678 \\
\hline & $0.5 \mathrm{~g} / 100 \mathrm{~g}$ a-MACS-2496 & 76.2 & 7.7 & 3.5 & 44 & 65.7 & 679 & 589 & 797 \\
\hline \multirow[t]{5}{*}{ HD-2189 } & Control & 69.8 & 4.5 & 1.6 & 52 & 74.5 & 472 & 458 & 617 \\
\hline & $0.25 \mathrm{~g} / 100 \mathrm{~g}$ a-HD-2189 & 70.1 & 4.4 & 1.4 & 55 & 73.9 & 523 & 485 & 646 \\
\hline & $0.5 \mathrm{~g} / 100 \mathrm{~g}$ a-HD-2 189 & 70.4 & 4.4 & 1.2 & 50 & 72.6 & 620 & 546 & 759 \\
\hline & $0.25 \mathrm{~g} / 100 \mathrm{~g}$ a-DWR-162 & 71.9 & 4.0 & 1.0 & 20 & 71.0 & 786 & 728 & 825 \\
\hline & $0.5 \mathrm{~g} / 100 \mathrm{~g}$ a-DWR-162 & 74.0 & 3.8 & 1.0 & 14 & 70.2 & 840 & 797 & 955 \\
\hline \multirow[t]{5}{*}{ MACS-2496 } & Control & 71.5 & 6.2 & 2.7 & 58 & 75.8 & 285 & 249 & 369 \\
\hline & $0.25 \mathrm{~g} / 100 \mathrm{~g}$ a-MACS-2496 & 71.8 & 6.0 & 2.5 & 64 & 74.0 & 308 & 280 & 411 \\
\hline & $0.5 \mathrm{~g} / 100 \mathrm{~g}$ a-MACS-2496 & 72.1 & 6.0 & 2.5 & 51 & 73.7 & 333 & 309 & 460 \\
\hline & $0.25 \mathrm{~g} / 100 \mathrm{~g}$ a-DWR-39 & 73.5 & 5.6 & 2.6 & 49 & 73.1 & 428 & 404 & 478 \\
\hline & $0.5 \mathrm{~g} / 100 \mathrm{~g}$ a-DWR-39 & 75.6 & 5.1 & 2.6 & 40 & 72.0 & 498 & 442 & 550 \\
\hline
\end{tabular}

"a-arabinoxylan.

flours obtained from HD-2189 and MACS-2496 varieties. Dough stability decreased on addition of arabinoxylans for all the flours and decreased by $0.6 \mathrm{~min}$ in DWR-162 flour when $0.5 \mathrm{~g} / 100 \mathrm{~g}$ arabinoxylan was added. There were marginal changes in mixing tolerance index (MTI) of flours, obtained from all the wheat varieties.

\subsubsection{Effect of Arabinoxylans from Good Chapati Making Quality (GCMQ) Whole Wheat Flours to Poor Chapati Making Quality (PCMQ) Whole Wheat Flours and Vice-Versa}

Water absorption increased by $0.3 \%$ and $0.6 \%$ on addition of 0.25 and $0.5 \mathrm{~g} / 100 \mathrm{~g}$ arabinoxylans from HD-2189 flour in DWR-162 flour, respectively. Similarly, WA increased by $0.3 \%$ and $0.7 \%$ on addition of 0.25 and $0.5 \mathrm{~g} / 100 \mathrm{~g}$ arabinoxylans from MACS-2496 flour in DWR-39 flour, respectively.

However, WA increased by $2.1 \%$ and $4.2 \%$ on addition of 0.25 and $0.5 \mathrm{~g} / 100 \mathrm{~g}$ DWR-162 flour arabinoxy- lans, respectively to HD-2189 flour. Similarly WA increased by $2.0 \%$ and $4.1 \%$ on addition of 0.25 and 0.5 g/100g DWR-39 flour arabinoxylans, respectively to MACS-2496 flour. The results clearly indicated that arabinoxylans from GCMQ flour exhibited higher water absorption. DDT decreased by 0.1 and $0.2 \mathrm{~min}$ on adding 0.25 and $0.5 \mathrm{~g} / 100 \mathrm{~g}$ arabinoxylans, respectively from PCMQ flour to GCMQ flour while DDT decreased by 0.5 to $1.1 \mathrm{~min}$ when arabinoxylans from GCMQ flour were added to PCMQ flour. The decrease in dough stability was $1 \mathrm{~min}$, when $0.5 \mathrm{~g} / 100 \mathrm{~g}$ of HD-2189 flour arabinoxylan was added to DWR-162 flour. Least decrease (0.1 min) in dough stability was observed when 0.5 $\mathrm{g} / 100 \mathrm{~g}$ of DWR-39 flour arabinoxylan was added to MACS-2496 flour. There were marginal changes in mixing tolerance index values, when arabinoxylans from GCMQ flour were added to PCMQ flour indicating greater stability of the dough during mixing.

Although the increase in WA was observed upon addi- 
tion of arabinoxylans in all the cases, it was more with the addition of isolated arabinoxylans of GCMQ flour, which might be due to their high arabinose content. There was a positive effect observed in PCMQ flour on adding isolated arabinoxylans from GCMQ flour. Arabinoxylans imbibe and hold water with the crosslinking density of the gel network and thus increase farinograph water absorption [24,25]. Jelaca and Hlynka [24] reported that arabinoxylan additions bring about changes in dough stability. During dough mixing, arabinoxylans act during the agglomeration of gluten following the breakdown of gluten structures and this may be the reason in alterations in rheological properties of whole wheat flour [26].

\subsection{Effect of Arabinoxylans on the Amylograph Characteristics of Whole Wheat Flour}

\subsubsection{Effect of Arabinoxylans on the Same Variety of Whole Wheat Flour}

Isolated arabinoxylans were added at 0.25 and $0.5 \mathrm{~g} / 100 \mathrm{~g}$ in the same variety of whole wheat flour and amylograph characteristics of whole wheat flour was studied (Table 2). Pasting temperature (PT) decreased from $67.7^{\circ} \mathrm{C}$ to $67.3^{\circ} \mathrm{C}, 67.1^{\circ} \mathrm{C}$ for DWR-162 flour and $67.3^{\circ} \mathrm{C}$ to $67.2^{\circ} \mathrm{C}$, $66.4^{\circ} \mathrm{C}$ for DWR-39 flour upon addition of 0.25 and 0.5 $\mathrm{g} / 100 \mathrm{~g}$ arabinoxylans from the same variety of wheat. PT was high $\left(74.5^{\circ} \mathrm{C}\right.$ and $\left.75.8^{\circ} \mathrm{C}\right)$ and it decreased to $73.9^{\circ} \mathrm{C}$, $72.6^{\circ} \mathrm{C}$ and $74.0^{\circ} \mathrm{C}, 73.7^{\circ} \mathrm{C}$ for $\mathrm{HD}-2189$ flour and MACS-2496 flour upon addition of 0.25 and $0.5 \mathrm{~g} / 100 \mathrm{~g}$ arabinoxylans from the same variety of wheat. Higher reduction in PT was observed for PCMQ flours. Peak viscosity (PV) increased from 470 to $712,864 \mathrm{BU}$ and 530 to $776,842 \mathrm{BU}$ upon addition of $0.25,0.5 \mathrm{~g} / 100 \mathrm{~g}$ arabinoxylans from same variety of wheat for DWR-162 flour and DWR-39 flour, respectively. PV increased from 472 to $523,620 \mathrm{BU}$ and 285 to $308,333 \mathrm{BU}$ upon addition of $0.25,0.5 \mathrm{~g} / 100 \mathrm{~g}$ arabinoxylans from same variety of wheat for HD-2189 flour and MACS-2496 flour, respectively. The increase in PV was high (312-394 BU) for GCMQ flours and it was low (48 - $148 \mathrm{BU}$ ) for PCMQ flours upon addition of $0.5 \mathrm{~g} / 100 \mathrm{~g}$ arabinoxylans. Similarly the increase in cold paste viscosity (CPV) was high (298-365 BU) for GCMQ flours and it was low (91 - $142 \mathrm{BU}$ ) for PCMQ flours upon addition of $0.5 \mathrm{~g} / 100 \mathrm{~g}$ arabinoxylans.

\subsubsection{Effect of Arabinoxylans from Good Chapati Making Quality (GCMQ) Whole Wheat Flours to Poor Chapati Making Quality (PCMQ) Whole Wheat Flours and Vice-Versa}

Pasting temperature (PT) decreased from $67.7^{\circ} \mathrm{C}$ to $66.4^{\circ} \mathrm{C}, 65.6^{\circ} \mathrm{C}$ for DWR-162 flour upon addition of 0.25 and $0.5 \mathrm{~g} / 100 \mathrm{~g}$ arabinoxylans from HD-2189 flour and $67.3^{\circ} \mathrm{C}$ to $66.2^{\circ} \mathrm{C}, 65.7^{\circ} \mathrm{C}$ for DWR-39 flour upon addition of 0.25 and $0.5 \mathrm{~g} / 100 \mathrm{~g}$ arabinoxylans from MACS-2496 flour, respectively. PT decreased from $74.5^{\circ} \mathrm{C}$ to $71.0^{\circ} \mathrm{C}$, $70.2^{\circ} \mathrm{C}$ for HD-2189 flour upon addition of 0.25 and 0.5 $\mathrm{g} / 100 \mathrm{~g}$ arabinoxylans from DWR-162 flour and $75.8^{\circ} \mathrm{C}$ to $73.1^{\circ} \mathrm{C}, 72.0^{\circ} \mathrm{C}$ for MACS-2496 flour upon addition of 0.25 and $0.5 \mathrm{~g} / 100 \mathrm{~g}$ arabinoxylans from DWR-39 flour, respectively. Higher reduction in PT was observed for PCMQ flours when arabinoxylans from GCMQ flours were added. Peak viscosity (PV) increased from 470 to 536, $601 \mathrm{BU}$ for DWR-162 flour upon addition of 0.25 and $0.5 \mathrm{~g} / 100 \mathrm{~g}$ arabinoxylans from HD-2189 flour and 530 to 552,679 BU for DWR-39 flour upon addition of 0.25 and $0.5 \mathrm{~g} / 100 \mathrm{~g}$ arabinoxylans from MACS-2496 flour, respectively. PV increased from 472 to $786,840 \mathrm{BU}$ for HD-2189 flour upon addition of 0.25 and $0.5 \mathrm{~g} / 100 \mathrm{~g}$ arabinoxylans from DWR-162 flour and 285 to 428,498 BU for MACS-2496 flour upon addition of 0.25 and 0.5 $\mathrm{g} / 100 \mathrm{~g}$ arabinoxylans from DWR-39 flour, respectively. The increase in PV was high when arabinoxylans from GCMQ flours were added in PCMQ flours. Similarly the increase in CPV was high (213 - $368 \mathrm{BU})$ for PCMQ flours upon $0.5 \mathrm{~g} / 100 \mathrm{~g}$ addition of arabinoxylans from GCMQ flours and it was low (131 - 149 BU) for GCMQ flours upon addition of $0.5 \mathrm{~g} / 100 \mathrm{~g}$ arabinoxylans from PCMQ flours.

It was observed that when whole wheat flours were added with isolated arabinoxylans of GCMQ flours, which have high arabinose-xylose ratio, the cold paste viscosity was very high compared to the other variations (Table 2). Yin and Walker [27] reported that water soluble arabinoxylans on adding to wheat flour exhibited positive effect on rheological properties by increasing dough paste viscosity. Earlier studies indicate that, addition of high molecular weight arabinoxylans increase and low molecular weight arabinoxylans decrease dough development time [28], however, in the present study it was based on $\mathrm{A} / \mathrm{X}$ ratio, higher the ratio better was the dough quality.

\subsection{Effect of Arabinoxylans on the Chapati Making Quality of Whole Wheat Flour}

\subsubsection{Effect of Arabinoxylans on the Same Variety of Whole Wheat Flour}

1) Objective evaluation of chapatis

Chapatis were prepared from whole wheat flour upon addition of 0.25 and $0.5 \mathrm{~g} / 100 \mathrm{~g}$ arabinoxylans. The puffed height of chapatis increased significantly ( $\mathrm{p} \leq$ 0.05 ) on addition of isolated arabinoxylans of same variety to the whole wheat flours (Table 3). The puffed height of chapatis prepared from DWR-162, DWR-39, HD-2189 and MACS-2496 wheat varieties upon adding 
Table 3. Chapati making quality of wheat flours added with isolated arabinoxylans.

\begin{tabular}{|c|c|c|c|}
\hline Wheat Varieties & Variations & Puffed height (cms) & Shear force $(\mathrm{N})$ \\
\hline \multirow[t]{5}{*}{ DWR-162 } & Control & $5.5^{\mathrm{a}} \pm 0.2$ & $5.8^{\mathrm{a}} \pm 0.3$ \\
\hline & $0.25 \mathrm{~g} / 100 \mathrm{~g}$ arabinoxylan & $6.2^{\mathrm{c}} \pm 0.1$ & $4.8^{\mathrm{c}} \pm 0.2$ \\
\hline & $0.5 \mathrm{~g} / 100 \mathrm{~g}$ arabinoxylan & $6.5^{\mathrm{d}} \pm 0.2$ & $3.9^{\mathrm{d}} \pm 0.1$ \\
\hline & $0.25 \mathrm{~g} / 100 \mathrm{~g}$ HD-2189 arabinoxylan & $5.8^{\mathrm{b}} \pm 0.1$ & $5.5^{\mathrm{b}} \pm 0.1$ \\
\hline & $0.5 \mathrm{~g} / 100 \mathrm{~g}$ HD-2189 arabinoxylan & $6.0^{\mathrm{bc}} \pm 0.1$ & $4.9^{\mathrm{c}} \pm 0.1$ \\
\hline \multirow[t]{5}{*}{ DWR-39 } & Control & $5.3^{\mathrm{a}} \pm 0.2$ & $5.6^{\mathrm{a}} \pm 0.2$ \\
\hline & $0.25 \mathrm{~g} / 100 \mathrm{~g}$ arabinoxylan & $6.1^{\mathrm{c}} \pm 0.1$ & $4.7^{\mathrm{c}} \pm 0.1$ \\
\hline & $0.5 \mathrm{~g} / 100 \mathrm{~g}$ arabinoxylan & $6.4^{\mathrm{d}} \pm 0.1$ & $3.7^{\mathrm{d}} \pm 0.2$ \\
\hline & $0.25 \mathrm{~g} / 100 \mathrm{~g}$ MACS-2496 arabinoxylan & $5.5^{\mathrm{b}} \pm 0.1$ & $5.4^{\mathrm{b}} \pm 0.2$ \\
\hline & $0.5 \mathrm{~g} / 100 \mathrm{~g}$ MACS-2496 arabinoxylan & $5.9^{\mathrm{c}} \pm 0.1$ & $4.6^{\mathrm{c}} \pm 0.1$ \\
\hline \multirow[t]{5}{*}{ HD-2189 } & Control & $4.8^{\mathrm{a}} \pm 0.1$ & $7.0^{\mathrm{a}} \pm 0.2$ \\
\hline & $0.25 \mathrm{~g} / 100 \mathrm{~g}$ arabinoxylan & $5.3^{\mathrm{b}} \pm 0.1$ & $6.9^{\mathrm{b}} \pm 0.1$ \\
\hline & $0.5 \mathrm{~g} / 100 \mathrm{~g}$ arabinoxylan & $5.6^{\mathrm{c}} \pm 0.2$ & $6.0^{\mathrm{c}} \pm 0.1$ \\
\hline & $0.25 \mathrm{~g} / 100 \mathrm{~g}$ DWR-162 arabinoxylan & $6.0^{\mathrm{d}} \pm 0.1$ & $4.4^{\mathrm{d}} \pm 0.1$ \\
\hline & $0.5 \mathrm{~g} / 100 \mathrm{~g}$ DWR-162 arabinoxylan & $6.3^{\mathrm{d}} \pm 0.1$ & $4.2^{\mathrm{e}} \pm 0.1$ \\
\hline \multirow[t]{5}{*}{ MACS-2496 } & Control & $4.6^{\mathrm{a}} \pm 0.1$ & $4.8^{\mathrm{a}} \pm 0.2$ \\
\hline & $0.25 \mathrm{~g} / 100 \mathrm{~g}$ arabinoxylan & $4.9^{\mathrm{b}} \pm 0.3$ & $4.6^{\mathrm{b}} \pm 0.3$ \\
\hline & $0.5 \mathrm{~g} / 100 \mathrm{~g}$ arabinoxylan & $5.1^{\mathrm{c}} \pm 0.5$ & $4.3^{\mathrm{c}} \pm 0.1$ \\
\hline & $0.25 \mathrm{~g} / 100 \mathrm{~g}$ DWR-39 arabinoxylan & $5.3^{\mathrm{d}} \pm 0.3$ & $3.9^{\mathrm{d}} \pm 0.1$ \\
\hline & $0.5 \mathrm{~g} / 100 \mathrm{~g}$ DWR-39 arabinoxylan & $5.6^{\mathrm{d}} \pm 0.1$ & $3.6^{\mathrm{e}} \pm 0.1$ \\
\hline
\end{tabular}

*Data reported are expressed as mean $\pm \mathrm{SD}$; Means followed by different letters in the same column box differ significantly [p $\leq 0.05]$.

$0.25 \mathrm{~g} / 100 \mathrm{~g}$ isolated arabinoxylans of same variety increased by $0.7,0.8,0.5$ and $0.3 \mathrm{~cm}$, respectively; upon adding $0.5 \mathrm{~g} / 100 \mathrm{~g}$ isolated arabinoxylans of same variety increased by $1.0,1.1,0.8$ and $0.5 \mathrm{~cm}$, respectively. The shear force of chapatis prepared from DWR-162, DWR39, HD-2189 and MACS-2496 wheat varieties upon adding $0.25 \mathrm{~g} / 100 \mathrm{~g}$ isolated arabinoxylans of same variety decreased by $1.0,0.9,0.1$ and $0.2 \mathrm{~N}$, respectively; upon adding $0.5 \mathrm{~g} / 100 \mathrm{~g}$ isolated arabinoxylans of same variety decreased by $1.9,1.9,1.0$ and $0.5 \mathrm{~N}$, respectively.

\section{2) Subjective evaluation of chapatis}

The different attributes of sensory characteristics as judged by ten panellists are presented in Table 4 . There were no significant changes in appearance of chapatis prepared from whole wheat flours containing added arabinoxylans. Tearing strength of chapatis decreased upon addition of arabinoxylans indicating that the chapatis were soft, which was also evident from objective measurement of shear force. The scores for pliability, aroma and eating quality increased on addition of isolated arabinoxylans.

\subsubsection{Effect of Arabinoxylans from Good Chapati Making Quality (GCMQ) Whole Wheat Flour to Poor Chapati Making Quality (PCMQ) Whole Wheat Flour and Vice-Versa \\ 1) Objective evaluation of chapatis}

The puffed height of chapatis prepared from DWR162 flour and DWR-39 flour on addition of isolated arabinoxylans of HD-2189 flour and MACS-2496 flour increased by $0.3-0.5 \mathrm{cms}$ and $0.2-0.6 \mathrm{cms}$, respectively. The puffed height of chapatis prepared from HD-2189 flour and MACS-2496 flour on addition of isolated arabinoxylans of DWR-162 flour and DWR-39 flour increased by $1.2-1.4 \mathrm{cms}$ and $0.7-1.0 \mathrm{cms}$, respectively (Table 3). The increase in puffed height was more when treated with arabinoxylans of GCMQ flour than the arabinoxylans of PCMQ flour.

The shear force of chapatis prepared from DWR-162 flour and DWR-39 flour on addition of isolated arabinoxylans of HD-2189 flour and MACS-2496 flour decreased by $0.3-0.9$ and $0.2-1.0 \mathrm{~N}$, respectively. The 
Table 4. Effect of arabinoxylans on sensory properties of chapattis.

\begin{tabular}{|c|c|c|c|c|c|c|c|}
\hline $\begin{array}{c}\text { Wheat } \\
\text { Varieties }\end{array}$ & Arabinoxylans & Appearance (10) & $\begin{array}{c}\text { Shear force } \\
(10)\end{array}$ & Pliability (10) & Aroma (10) & $\begin{array}{c}\text { Eating quality } \\
(20)\end{array}$ & $\begin{array}{c}\text { Overall Quality } \\
(60)\end{array}$ \\
\hline \multirow{5}{*}{ DWR-162 } & Control & $8.6^{\mathrm{a}} \pm 0.2$ & $8.5^{\mathrm{c}} \pm 0.3$ & $8.4^{\mathrm{c}} \pm 0.2$ & $8.5^{\mathrm{a}} \pm 0.2$ & $18.4^{\mathrm{c}} \pm 0.1$ & $52.4^{\mathrm{c}} \pm 0.9$ \\
\hline & $0.25 \mathrm{~g} / 100 \mathrm{~g}$ arabinoxylan & $8.7^{\mathrm{a}} \pm 0.3$ & $9.0^{\mathrm{b}} \pm 0.4$ & $8.9^{\mathrm{b}} \pm 0.3$ & $8.6^{\mathrm{a}} \pm 0.2$ & $18.8^{\mathrm{b}} \pm 0.9$ & $54.0^{\mathrm{abc}} \pm 1.0$ \\
\hline & $0.5 \mathrm{~g} / 100 \mathrm{~g}$ arabinoxylan & $8.7^{\mathrm{a}} \pm 0.4$ & $9.5^{\mathrm{a}} \pm 0.3$ & $9.4^{\mathrm{a}} \pm 0.2$ & $8.7^{\mathrm{a}} \pm 0.2$ & $19.0^{\mathrm{a}} \pm 0.4$ & $55.3^{\mathrm{a}} \pm 0.7$ \\
\hline & $0.25 \mathrm{~g} / 100 \mathrm{~g}$ HD-2189 arabinoxylan & $8.6^{\mathrm{a}} \pm 0.3$ & $8.7^{\mathrm{c}} \pm 0.2$ & $8.6^{\mathrm{c}} \pm 0.2$ & $8.6^{\mathrm{a}} \pm 0.2$ & $18.6^{\mathrm{b}} \pm 0.5$ & $53.1^{\mathrm{bc}} \pm 1.1$ \\
\hline & $0.5 \mathrm{~g} / 100 \mathrm{~g}$ HD-2189 arabinoxylan & $8.6^{\mathrm{a}} \pm 0.1$ & $8.9^{\mathrm{b}} \pm 0.1$ & $9.0^{\mathrm{b}} \pm 0.2$ & $8.6^{\mathrm{a}} \pm 0.2$ & $18.8^{\mathrm{b}} \pm 0.2$ & $53.9^{\mathrm{abc}} \pm 0.4$ \\
\hline \multirow{5}{*}{ DWR-39 } & Control & $8.7^{\mathrm{a}} \pm 0.3$ & $8.5^{\mathrm{d}} \pm 0.2$ & $8.4^{\mathrm{c}} \pm 0.1$ & $8.5^{\mathrm{c}} \pm 0.2$ & $18.2^{\mathrm{b}} \pm 0.1$ & $52.0^{\mathrm{d}} \pm 0.4$ \\
\hline & $0.25 \mathrm{~g} / 100 \mathrm{~g}$ arabinoxylan & $8.7^{\mathrm{a}} \pm 0.2$ & $9.2^{\mathrm{b}} \pm 0.3$ & $9.0^{\mathrm{a}} \pm 0.1$ & $8.7^{b} \pm 0.3$ & $18.5^{\mathrm{a}} \pm 0.2$ & $54.1^{\mathrm{b}} \pm 0.2$ \\
\hline & $0.5 \mathrm{~g} / 100 \mathrm{~g}$ arabinoxylan & $8.9^{\mathrm{a}} \pm 0.3$ & $9.5^{\mathrm{a}} \pm 0.1$ & $9.2^{\mathrm{a}} \pm 0.1$ & $8.9^{\mathrm{a}} \pm 0.4$ & $18.9^{\mathrm{a}} \pm 0.2$ & $55.4^{\mathrm{a}} \pm 0.2$ \\
\hline & $0.25 \mathrm{~g} / 100 \mathrm{~g}$ MACS-2496 arabinoxylan & $8.7^{\mathrm{a}} \pm 0.3$ & $8.8^{\mathrm{cd}} \pm 0.1$ & $8.5^{\mathrm{b}} \pm 0.1$ & $8.7^{\mathrm{b}} \pm 0.6$ & $18.3^{\mathrm{b}} \pm 0.7$ & $53.0^{c} \pm 0.5$ \\
\hline & $0.5 \mathrm{~g} / 100 \mathrm{~g}$ MACS-2496 arabinoxylan & $8.7^{\mathrm{a}} \pm 0.3$ & $8.9^{\mathrm{c}} \pm 0.1$ & $8.8^{\mathrm{b}} \pm 0.1$ & $8.7^{\mathrm{b}} \pm 0.1$ & $18.4^{\mathrm{b}} \pm 0.4$ & $53.5^{\mathrm{bc}} \pm 0.5$ \\
\hline \multirow{5}{*}{ HD-2189 } & Control & $7.3^{\mathrm{a}} \pm 0.3$ & $7.7^{\mathrm{e}} \pm 0.2$ & $7.4^{\mathrm{d}} \pm 0.1$ & $6.2^{\mathrm{b}} \pm 0.2$ & $14.2^{\mathrm{c}} \pm 0.2$ & $42.8^{\mathrm{e}} \pm 0.5$ \\
\hline & $0.25 \mathrm{~g} / 100 \mathrm{~g}$ arabinoxylan & $7.4^{\mathrm{a}} \pm 0.3$ & $8.3^{\mathrm{d}} \pm 0.2$ & $7.9^{c} \pm 0.1$ & $6.3^{b} \pm 0.2$ & $14.4^{\mathrm{c}} \pm 0.3$ & $44.3^{\mathrm{d}} \pm 0.6$ \\
\hline & $0.5 \mathrm{~g} / 100 \mathrm{~g}$ arabinoxylan & $7.4^{\mathrm{a}} \pm 0.4$ & $8.6^{\mathrm{c}} \pm 0.2$ & $8.2^{\mathrm{b}} \pm 0.1$ & $6.4^{\mathrm{b}} \pm 0.1$ & $14.8^{\mathrm{b}} \pm 0.3$ & $45.4^{\mathrm{c}} \pm 0.2$ \\
\hline & $0.25 \mathrm{~g} / 100 \mathrm{~g}$ DWR-162 arabinoxylan & $7.4^{\mathrm{a}} \pm 0.2$ & $8.9^{\mathrm{b}} \pm 0.2$ & $8.6^{\mathrm{a}} \pm 0.1$ & $6.6^{\mathrm{a}} \pm 0.1$ & $15.1^{\mathrm{a}} \pm 0.4$ & $46.6^{\mathrm{b}} \pm 0.3$ \\
\hline & $0.5 \mathrm{~g} / 100 \mathrm{~g}$ DWR-162 arabinoxylan & $7.4^{\mathrm{a}} \pm 0.3$ & $9.2^{\mathrm{a}} \pm 0.2$ & $8.9^{\mathrm{a}} \pm 0.2$ & $6.7^{\mathrm{a}} \pm 0.1$ & $15.3^{\mathrm{a}} \pm 0.4$ & $47.5^{\mathrm{a}} \pm 0.2$ \\
\hline \multirow{5}{*}{ MACS-2496 } & Control & $7.3^{\mathrm{a}} \pm 0.3$ & $7.4^{\mathrm{e}} \pm 0.3$ & $7.2^{\mathrm{e}} \pm 0.3$ & $6.2^{\mathrm{a}} \pm 0.1$ & $14.2^{\mathrm{c}} \pm 0.9$ & $42.3^{\mathrm{c}} \pm 1.1$ \\
\hline & $0.25 \mathrm{~g} / 100 \mathrm{~g}$ arabinoxylan & $7.4^{\mathrm{a}} \pm 0.2$ & $8.5^{\mathrm{d}} \pm 0.3$ & $7.6^{\mathrm{d}} \pm 0.4$ & $6.2^{\mathrm{a}} \pm 0.1$ & $14.4^{\mathrm{c}} \pm 0.9$ & $44.1^{b} \pm 0.2$ \\
\hline & $0.5 \mathrm{~g} / 100 \mathrm{~g}$ arabinoxylan & $7.4^{\mathrm{a}} \pm 0.3$ & $8.8^{\mathrm{c}} \pm 0.1$ & $7.9^{c} \pm 0.2$ & $6.3^{\mathrm{a}} \pm 0.1$ & $14.9^{\mathrm{b}} \pm 0.8$ & $45.3^{\mathrm{bc}} \pm 1.0$ \\
\hline & $0.25 \mathrm{~g} / 100 \mathrm{~g}$ DWR-39 arabinoxylan & $7.4^{\mathrm{a}} \pm 0.2$ & $9.3^{\mathrm{b}} \pm 0.1$ & $8.2^{\mathrm{b}} \pm 0.1$ & $6.3^{\mathrm{a}} \pm 0.2$ & $15.3^{\mathrm{a}} \pm 0.7$ & $46.5^{\mathrm{bc}} \pm 0.5$ \\
\hline & $0.5 \mathrm{~g} / 100 \mathrm{~g}$ DWR-39 arabinoxylan & $7.4^{\mathrm{a}} \pm 0.3$ & $9.6^{\mathrm{a}} \pm 0.2$ & $8.4^{\mathrm{a}} \pm 0.1$ & $6.3^{\mathrm{a}} \pm 0.1$ & $15.5^{\mathrm{a}} \pm 0.7$ & $47.2^{\mathrm{a}} \pm 0.7$ \\
\hline
\end{tabular}

*Data reported are expressed as mean $\pm \mathrm{SD}$; Means followed by different letters in the same column box differ significantly $(\mathrm{p} \leq 0.05)$.

shear force of chapatis prepared from HD-2189 flour and MACS-2496 flour on addition of isolated arabinoxylans of DWR-162 flour and DWR-39 flour decreased by 2.6 2.8 and $0.9-1.2 \mathrm{~N}$, respectively (Table 3). The decrease in shear force was more when treated with arabinoxylans of GCMQ flour than the arabinoxylans of PCMQ flour. Lower shear force denotes that the chapatis have softer texture hence easy to tear [2] [Haridas Rao, 1993]. Soft texture is a desirable property of chapati that makes it easy to chew.

\section{2) Subjective evaluation of chapatis}

Chapatis prepared from DWR-162 flour and DWR-39 flour on adding isolated arabinoxylans of HD-2189 flour and MACS-2496 flour showed increase in the scores for tearing strength, pliability, aroma and eating quality. However, there was no significant $(\mathrm{p} \leq 0.05)$ difference in appearance of chapatis and the increase in scores of the former was not as high as the scores of chapatis prepared from DWR-162 flour and DWR-39 flour treated with isolated arabinoxylans of the same variety.
There was no significant difference in appearance and aroma of chapatis prepared from HD-2189 flour and MACS-2496 flour on adding isolated arabinoxylans of DWR-162 flour and DWR-39 flour. Significant improvement in the tearing strength and pliability of chapatis was observed in chapatis prepared from HD-2189 flour and MACS-2496 flour on adding isolated arabinoxylans of DWR-162 flour and DWR-39 flour (Table 4). Eating quality is an attribute observed during chewing and biting of chapatis. Chapatis having moderate tearing strength and more pliability result in a product requiring lesser effort to chew the chapatis. Tougher chapatis require more effort for biting, chewing, tearing action and such a mouthfeel is not desirable. Sensory scores for eating quality of HD-2189 flour and MACS-2496 flour chapatis on adding isolated arabinoxylans of DWR-162 flour and DWR-39 flour increased significantly. Isolated arabinoxylans of DWR-162 and DWR-39 treated whole wheat flours had positive impact on chapatis. Possible explanation would be that since isolated arabinoxylans of DWR- 
162 and DWR-39 varieties had high arabinose to xylose ratio which exerts their functional role by means of their molecular structure, gelling capacity and influence the water distribution and water availability and there by influencing the chapati quality.

Earlier studies carried out on bread indicated that textural properties of bread are attributed to the presence of arabinoxylans in wheat as water absorption are governed by both protein and arabinoxylan content and their interactions [29]. Chapati water absorption and damaged starch are critical factors in determining the quality of chapati [30]. It is also reported that arabinoxylans exerts their functional role by means of their molecular structure, gelling capacity and influence the water distribution and water availability and thereby influencing the loaf volume and in turn the bread quality [31]. In the present study, dough characteristics upon addition of arabinoxylans had improved which was evident by increase in water absorption and viscosity of the dough. The positive impact on dough rheology has brought about the positive impact in chapati quality which is evident from textural and sensory property.

\section{Conclusion}

Addition of isolated arabinoxylans to whole wheat flours has improved the overall quality of chapatis. However, the isolated arabinoxylans from good chapati making wheat varieties have resulted in soft textured chapatis with improvement in overall quality compared to that of isolated arabinoxylans of poor chapati making wheat varieties. These improvements are attributed to differences in their arabinose to xylose ratio. Thus, the studies showed that the quality of chapatis can be improved by the addition of arabinoxylans isolated from good chapati making wheat varieties.

\section{Acknowledgements}

The author MSH thanks DST, (SR/WOS-A/LS156/2006), New Delhi, India, for the award of fellowship.

\section{REFERENCES}

[1] P. Haridas Rao, K. Leelavathi and S. R. Shurpalekar "Test Baking of Chapati-Development of a Method," Cereal Chemistry, Vol. 63, No. 4, 1986, pp. 297-303.

[2] P. Haridas Rao, "Chapati and Related Products," In: R. Macrae, R. K. Robinson and M. J. Sadler, Eds., Encyclopaedia of Food Science, Food Technology and Nutrition, Vol. II, Academic Press, London, 1993, pp. 795-801.

[3] K. G. Shalini and A. Laxmi, "Influence of Additives on Rheological Characteristics of Whole-Wheat Dough and Quality of Chapatti (Indian Unleavened Flat Bread)," Food Hydrocolloids, Vol. 21, No. 1, 2007, pp. 110-117.

\section{doi:10.1016/j.foodhyd.2006.03.002}

[4] J. R. Pritchard, G. J. Lawrence, O. Larroque, Z. li, H. K. C. Laidlaw, M. K. Morell and S. Rahman, "A Survey of $\beta$-Glucan and Arabinoxylan Content in Wheat," Journal of the Science of Food and Agriculture, Vol. 91, No. 7, 2011, pp. 1298-1303. doi:10.1002/jsfa.4316

[5] M. Wang, H. D. Sapirstein, A. S. Machet and J. E. Dexter, "Composition and Distribution of Pentosans in Millstreams of Different Hard Spring Wheats," Cereal Chemistry, Vol. 83, No. 2, 2006, pp. 161-168. doi:10.1094/CC-83-0161

[6] J. Michniewicz, C. G. Biliaderis and W. Bushuk, "Effect of Added Pentosans on Some Physical and Technological Characteristics of Whole Wheat Flour and Gluten," Cereal Chemistry, Vol. 68, 1991, pp. 252-258.

[7] J. A. Delcour, S. Vanhamel and R. C. Hoseney, "Physicochemical and Functional Properties of Rye Non-Starch Polysaccharides. II Impact of Fraction Containing Water Soluble Pentosans and Proteins on Gluten Starch Loaf Volumes," Cereal Chemistry, Vol. 68, No. 1, 1991, pp. 72-76.

[8] M. S. Izydorczyk and C. G. Biliaderis, "Cereal Arabinoxylans Advances in Structure and Physicochemical Properties," Carbohydrate Polymers, Vol. 28, No. 1, 1995, pp 33-48. doi:10.1016/0144-8617(95)00077-1

[9] R. Amado and H. Neukom, "Minor Constituents of Wheat Flour: The Pentosans," In: R. D. Hill and L. Menck, Eds., New Approaches to Research on Cereal Carbohydrates, Elseviers Science Publishers, Amsterdam, 1985, pp. 241251.

[10] F. Meuser and P. Suckow, "Non-Starch Polysaccharides," In: J. M. V. Blanshard, P. J. Frazier and T. Galliard, Eds., Chemistry and Physics of Baking, The Royal Society of Science, London, 1986, pp. 42-62.

[11] M. S. Hemalatha, B. T. Manu, S. G. Bhagwat, K. Leelavathi and U. J. S. Prasada Rao, "Protein Characteristics and Peroxidase Activities of Different Indian Wheat Varieties and Their Relationship to Chapati-Making Quality," European Food Research Technology, Vol. 225, No. 3-4, 2007, pp. 463-471. doi:10.1007/s00217-006-0441-7

[12] D. M. J. Santos, A. C. Gama and L. da Silva, "A Rheological Study of Wheat Starch-Water-Soluble Pentosans Mixtures under Hydrothermal Gelling Conditions," Journal of Food Science, Vol. 67, No. 9, 2002, pp. 3372-3380. doi:10.1111/j.1365-2621.2002.tb09593.x

[13] Z. Czuchajowska and Y. Pomeranz, "Protein Concentrates and Prime Starch from Wheat Flours," Cereal Chemistry, Vol. 70, No. 6, 1993, pp. 701-706.

[14] M. S. Izydorczyk, C. G. Biliaderis and W. Bushuk, "Oxidative Gelation Studies of Water-Soluble Pentosans from Wheat," Journal of Cereal Science, Vol. 11, No. 2, 1990, pp. 153-169. doi:10.1016/S0733-5210(09)80117-3

[15] C. J. A. Vinkx, H. R. Reynaert, P. J. Grobert and J. A. Delcour, "Physicochemical and Functional Properties of Rye Nonstarch Polysaccharides. Variability in the Structure of Water Soluble Arabinoxylans," Cereal Chemistry, Vol. 70, No. 3, 1993, pp. 311-317.

[16] M. Dubois, K. A. Gilles, J. K. Hamilton, P. A. Rebers and 
F. Smith, "Colorimetric Method for Determination of Sugars and Related Substances," Analytical Chemistry, Vol. 28, No. 3, 1956, pp. 350-356. doi:10.1021/ac60111a017

[17] Z. Dische, "A New Specific Colour Reaction of Hexuronic Acids," Journal of Biological Chemistry, Vol. 167, No. 1, 1947, pp. 189-198.

[18] J. S. Sawardekar, L. H. Slonekar and A. Jeanes, "Quantitative Determination of Monosaccharides as Their Alditol Acetates by Gas Liquid Chromatography," Analytical Chemistry, Vol. 37, No. 12, 1967, pp. 1602-1604. doi:10.1021/ac60231a048

[19] H. G. Albaum and Umbreit, "Differentiation between Ribose-3-phosphate and Ribose-5-phosphate by Means of the Orcinol-Pentose Reaction," Journal of Biological Chemistry, Vol. 167, No. 2, 1947, pp. 369-373.

[20] American Association of Cereal Chemists, "Approved Methods of AACC," 2006.

[21] G. D. Steel and J. H. Torrie, "Principles and Procedures of Statistics," McGraw Hill, New York, 1980.

[22] M. S. Dupont and R. R. Selvendran, "Hemicellulosic Polymers from the Cell Walls of Beeswing Wheat Bran: Part I, Polymers Solubilised by Alkali at $2^{\circ} \mathrm{C}$," Carbohydrate Research, Vol. 163, No. 1, 1987, pp. 99-113. doi:10.1016/0008-6215(87)80169-6

[23] D. C. Saxena, P. V. Salimath and P. Haridas Rao, "Indian Wheat Cultivars: Their Carbohydrate Profile and Its Relation to Tandoori Roti Quality," Food Chemistry, Vol. 68, No. 2, 2000, pp. 185-190. doi:10.1016/S0308-8146(99)00174-0

[24] S. L. Jelaca and I Hlynka, "Water Binding Capacity of Wheat Flour Crude Arabinoxylans and Their Relationship to Mixing Characteristics of Whole Wheat Flour," Cereal Chemistry, Vol. 48, 1971, pp. 211-222.
[25] G. Cleemput, S. P. Roels, M. Vanoort, P. J. Grobet and J. A. Delcour, "Heterogeneity in the Structure of Water Soluble Arabinoxylans in European Wheat Flour of Variable Bread Making Quality," Cereal Chemistry, Vol. 70, No. 3, 1993, pp. 324-329.

[26] M. Wang, T. V. Vliet and R. J. Hamer, "Evidence That Pentosans and Xylanase Affect the Re-Agglomeration of the Gluten Network," Journal of Cereal Science, Vol. 39, No. 3, 2004, pp. 341-349. doi:10.1016/j.jcs.2003.12.003

[27] Y. Yin and C. E. Walker, "Pentosans from Gluten Washing Waste Water Isolation, Characterizations and Role of Baking," Cereal Chemistry, Vol. 69, No. 6, 1992, pp. 592-596.

[28] C. G. Biliaderis, M. S. Izydorczyk and O. Rattan, "Effect of Arabinoxylans on Bread-Making Quality of Wheat Flours," Food Chemistry, Vol. 53, No. 2, 1995, pp. 165171. doi:10.1016/0308-8146(95)90783-4

[29] M. D. Shogren, Hashimoto and Y. Pomeranz, "Cereal Pentosans: Their Significance II Pentosans and Breadmaking Characteristics of Hard Red Winter Wheat Flours," Cereal Chemistry, Vol. 64, No. 1, 1987, pp. 3538.

[30] P. Prabhasankar, R. Saimanohar and L. R. Gowda, "Physicochemical and Biochemical Characterization of Selected Wheat Cultivars and Their Correlation to Chapati Making Quality," European Food Research and Technology, Vol. 214, No. 2, 2002, pp. 131-137. doi:10.1007/s00217-001-0435-4

[31] C. M. Courtin and J. A. Delcour, "Physicochemical and Breadmaking Properties of Low Molecular Weight Wheat Derived Arabinoxylans," Journal of Agricultural and Food Chemistry, Vol. 46, No. 10, 1998, pp. 4066-4073. doi: $10.1021 / \mathrm{j} 980339 \mathrm{t}$ 